\title{
Experimental Study on Effect of Injection Pressure to Spray Characteristics, Performance and Emissions of DieselEngine DI 20 C Using Biodiesel Fuel
}

\author{
Alham A. K. Mahanggi ${ }^{1}$, Bambang Sudarmanta ${ }^{2}$, Hary Soebagyo ${ }^{3}$ \\ $1,{ }^{2}$ Combustion and Energy System Laboratory, Department of Mechanical Engineering, ITS, Sukolilo Surabaya \\ 60111, Indonesia \\ ${ }^{3}$ Balai Besar Teknologi Kekuatan Struktur (B2TKS), Badan Pengkajian dan Penerapan Teknologi (BPPT), \\ Indonesia \\ Received:2 February 2018, Revised: 1 March 2018, Accepted: 31 March 2018
}

\begin{abstract}
Biodiesel as an alternative fuel can replace fossil fuels. However, biodiesel has a higher value of viscosity, density and surface tension to fossil fuels. Increasing the injection pressure on the injector is one solution to overcome the problem of high viscosity, density, and surface tension in biodiesel. This study aims to determine the effect of increasing injection pressure and injection timing variations on spray characteristics, performance and exhaust emissions diesel engine. Injection pressure namely 200, 210, $220,230 \mathrm{~kg} / \mathrm{cm}^{2}$ by setting the rotation of adjusting screw the injector. The results of this study were obtained by increasing the pressure injection of biodiesel fuel by $230 \mathrm{~kg} / \mathrm{cm}^{2}$ resulting in fuel spray characteristics better than the standard $200 \mathrm{~kg} / \mathrm{cm}^{2}$ and resulting improvements in the penetration length, spray angle, the average diameter size of each $30 \%, 28 \%$, and $9.78 \%$. And performance improvements and exhaust emissions also occur, namely Thermal Efficiency, Specific Fuel Consumption, and Smoke Opacity with values of $16.99 \%, 14.15 \%$, and $46.39 \%$ improved respectively.

Keywords: Biodiesel, Injector, Injection Pressure, Spray characteristic, Performance, Emission
\end{abstract}

\section{Introduction}

Indonesia still relies on the use of fossil fuels. Fossil fuels are non-sustainable energy sources, which are commonly used in industrial and transportation fields. For example in diesel engines, Solar, Dexlite, and Pertadex are the result of distillation of fractions from petroleum (fossil fuels), which the availability is limited. The use of fossil fuels also has a negative impact on the environment. Exhaust emissions from combustion of fuel are one of the main causes of the greenhouse effect (such as $\mathrm{CO}, \mathrm{CO}_{2}$, HC, etc.). With the adverse effects of the depletion of fossil fuels, alternative fuels are needed to reduce dependence on fossil fuels engine near or equal to using fossil fuels. This can be done by increasing injection pressure to improve biodiesel properties, namely viscosity, density, and surface tension.

Biodiesel is a fuel that is very potential to be used as a substitute for fossil fuels. This is because the raw materials derived from vegetable oils, can be renewed, can be produced periodically and easily obtained. However, fuel spray characteristics are influenced by the physical properties of fuel kind of density, viscosity and surface tension [1] where biodiesel is a fuel that has a higher value of viscosity, density, and surface tension but low at the heating value compared to fossil fuels. The higher value of viscosity, density, and surface tension on the biodiesel fuel causes the atomization of the fuel is not good and more difficult to mix with air which results in incomplete combustion. Therefore certain treatments are needed so that biodiesel fuel can be used and produce a performance on the engine near or equal to using fossil fuels. This can be done by increasing injection pressure to improve biodiesel properties, namely viscosity, density, and surface tension.

Sudarmanta [1] conducted a study on the transesterification of crude palm oil and spray characteristic tests using a diesel motor injector. It was produced that the properties of transesterification biodiesel, in this case, the viscosity, density, and surface tension were still slightly higher than the properties of diesel fuel. Experimental and computer simulations of spray characteristics showed that higher viscosity resulted in poor atomization characteristics, namely in the form of poorer evaporation. Whereas higher density and surface tension produce slightly more liquid forms, penetration, and droplet so that the gas phase distribution becomes narrower.

Some researchers carried out the experimental study on the effect of injection pressure variations using biodiesel fuel. Ahmad [2] conducted a study of the effect of injection pressure on performance on dual fuel diesel engines. Variations are made by changing the thick- 
ness of the shim or adjusting the washer according to the variation, namely 190 bar, 210 bar, 230 and $250 \mathrm{~kg} / \mathrm{cm}^{2}$ with a constant engine speed of $2000 \mathrm{rpm}$ and loading from $200 \mathrm{~W}$ to $2000 \mathrm{~W}$ at intervals of $200 \mathrm{~W}$, dual fuel system between biodiesel fuels with syn-gas. The best performance results obtained at a pressure of $250 \mathrm{~kg} / \mathrm{cm}^{2}$ with an increase in the percentage of thermal efficiency of $40,766 \%$ and spray angle $(\varnothing)$ of $29.41 \%$, and a decrease in the percentage of SFC biodiesel, SFC on dual fuel systems and spray length (L) of 30,766\%, 13,24\% and $19.23 \%$.

Mutyalu et al. [3] investigated the effect of fuel injection pressure on the performance and emissions characteristics of a diesel engine with Shea Olein Biodiesel fuel. The experiment was carried out on stationary water cooled naturally aspirated single cylinder 4-stroke and direct injection Kirloskar engine at a constant rated speed of $1500 \mathrm{rpm}$ and load at $2,79 \mathrm{~kW}$. The test was conducted at different injection pressures (190, 200, 210, 220, 230 bar). The best performance and emissions are produced at a pressure of 210 bar. Where the results of chart trends such as BSFC have decreased at a pressure of 210 bar. While at higher injection pressures, BSFC has increased because of higher momentum of fuel got impinges on cylinder walls leads to wastage of fuel and improper combustion. And $\mathrm{HC}$ and $\mathrm{CO}$ emissions also decrease at a pressure of 210 bar.

Table 1. Properties of Fuels

\begin{tabular}{|l|l|l|}
\hline Properties & Diesel Fossil & Bio Diesel \\
\hline Lower Caloric Value $(\mathrm{LHV})(\mathrm{kJ} / \mathrm{kg})$ & 46218.09 & 42542.54 \\
\hline Densityat $15^{\circ} \mathrm{C}\left(\mathrm{kg} / \mathrm{m}^{3}\right)$ & 857 & 875 \\
\hline Densityat $40^{\circ} \mathrm{C}\left(\mathrm{kg} / \mathrm{m}^{3}\right)$ & 844 & 857 \\
\hline KinematicsViscosityat $40{ }^{\circ} \mathrm{C}\left(\mathrm{mm}^{2} / \mathrm{s}\right)$ & 4.2 & 4.5 \\
\hline Surface Tension $($ dyne $/ \mathrm{cm})$ & 66 & 68 \\
\hline Cetane number & 53 & 58 \\
\hline
\end{tabular}

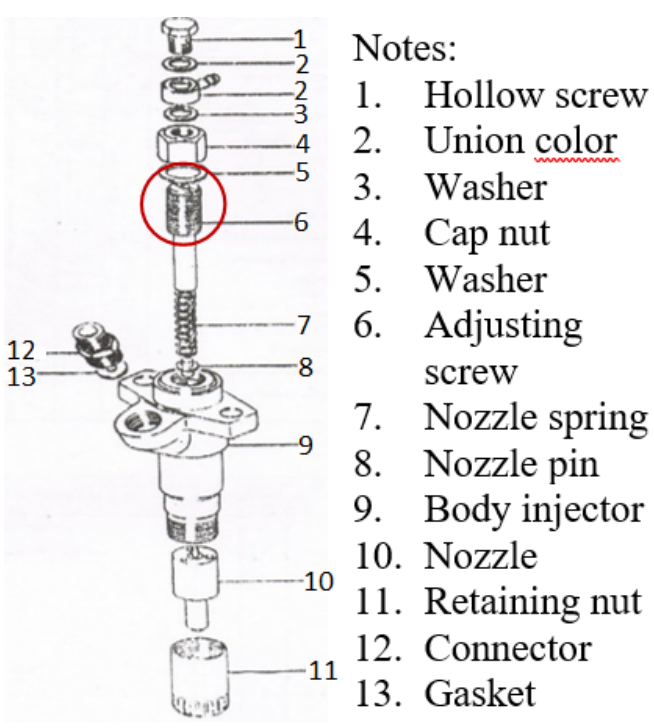

Figure 1. Injector Geometry

\section{Material and Method}

\subsection{Fuel Properties}

The biodiesel used in this test is B100 biodiesel from palm oil (CPO) obtained from PT. Wilmar Nabati Indonesia, where biodiesel in Indonesia uses more raw materials from palm oil because it is easily obtained [4]. But when compared to diesel fuel, the properties of biodiesel fuel have a higher value of viscosity, density, surface tension, and cetane number but low at the heating value. Table 1 shows differences in properties of diesel fuel and biodiesel.

\subsection{Spray Characteristic Test}

To find out the results of fuel atomization, spray characteristic tests were carried out using a Bosch pump tester with biodiesel fuel. Figure 1 shows the injector used in Diamond DI $20 \mathrm{C}$ diesel engines. Then the injection pressure variation is performed by setting the rotation in 


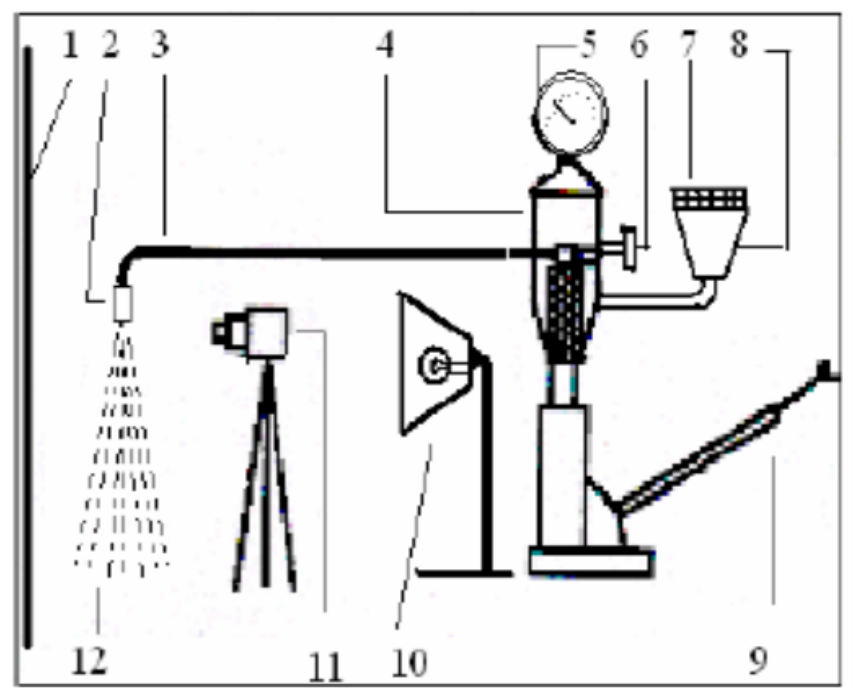

Notes:

1. Black screen

2. Injector nozzle

3. Injection pipeline

4. Pressure gauge

5. Shut off valve

6. Filter

7. Fuel tank

8. Lever

9. Light

10.Digital camera

11.Spray

Figure 2. Schematic ofspray characteristic testing

adjusting screw on the injector until the injection pressure will be tested, where injection pressure will be seen in the pressure gauge. The pressure variations in this study were 200, 210, 220 and $230 \mathrm{~kg} / \mathrm{cm}^{2}$. This test was carried out at the motor fuel laboratory of the mechanical engineering department, ITS Surabaya.

Figure 2 shows the fuel spray characteristic test series. After testing, the length of penetration and spray angle of the fuel will be measured, and the calculation of the average droplet size (SMD) with the formula approach from Jasuja [5] is as follows:

$$
S M D=2,25 \sigma^{0,25} \mu_{L}^{0,25} \dot{m}_{L}^{0,25} \Delta P_{L}^{-0,5} \rho_{A}^{-0,25}
$$

\subsection{Experimental Setup}

The study was carried out experimentally on a diesel engine with a constant speed of $2000 \mathrm{rpm}$. This test is carried out on a Diamond diesel engine DI $20 \mathrm{C}$ with the main shaft that has been coupled directly with the electrical generator as an electrical dynamometer. Data retrieval was carried out on each variation of load tested, which is 1000 Watts to 7000 Watts with the increment of 1000 Watts. This testing was carried out at the Workshop on Laboratory of Combustion and Energy Systems, Department of Mechanical Engineering, FTI-ITS Surabaya. Figure 2 shows the experimental method carried out in this test and the engine specifications shown in Table 2 .

Table 2. Engine specifications

\begin{tabular}{|l|l|l|}
\hline No. & Specification & Describtion \\
\hline 1. & Make & Diamond \\
2. & Model & DI 20 C \\
3. & Engine type & Four stroke, horizontal, water cooled \\
4. & Fuel injection & Direct injection \\
5. & Number of cylinders & Single cylinder \\
6. & Start of injection (BTDC) & $20^{\circ}$ \\
7. & Compression ratio & $16: 1$ \\
8. & Bore & $105 \mathrm{~mm}$ \\
9. & Stroke & $115 \mathrm{~mm}$ \\
10. & Cylinder volume & $1000 \mathrm{cc}$ \\
\hline
\end{tabular}




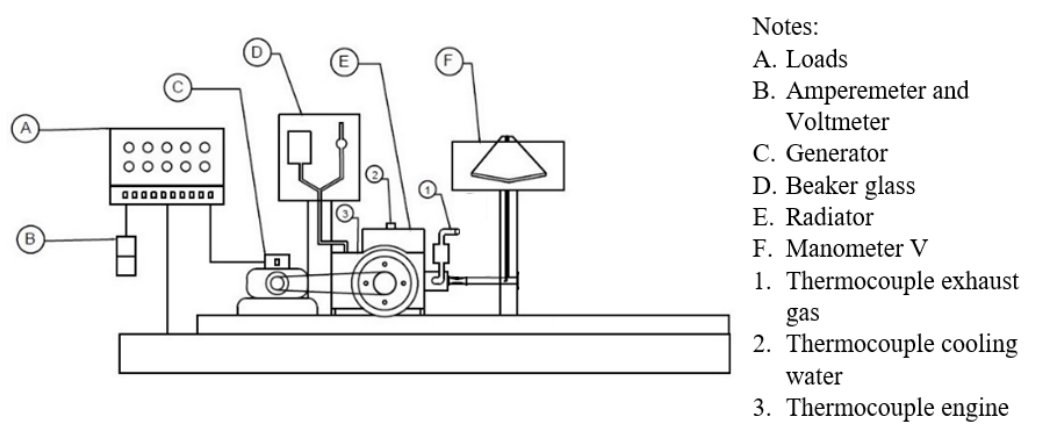

Figure 3. Schematic of engine performance test

\section{Results and Discussion}

The analysis of this study was carried out by compiling the results of the spray characteristics and experimental results of performance test and exhaust emission test.

\subsection{Result of Spray Injection Characteristic Test.}

Based on the properties of biodiesel that we have acknowledge, in the previous paragraph. Higher viscosity causes higher flow momentum so that the spray penetration length becomes longer, while higher surface tension makes it difficult for droplets of fuel to become smaller granules (secondary break up) which will then spread in all directions. This spread causes the contact surface of droplet fuel with less air, so the evaporation that occurs will be longer than the fuel which has a higher surface tension value.

Tests were carried out with pressure variations namely 200, 210, 220 and $230 \mathrm{~kg} / \mathrm{cm}^{2}$ using biodiesel fuel. The aim is to test the spray characteristics in order to find out the results of the atomization of biodiesel fuel at each injection pressure to approach the results of the atomization of diesel fuel. Atomization is converting liquid fuels injected by engine injectors into droplet shapes with certain patterns and directions [4]. Good atomization will also produce good engine performance and emissions, this is because fuel droplets are injected to form small particles which will collide with high-pressure air to mix and produce more complete combustion. Figure 4 shows the effect of increasing injection pressure on spray atomization and Table 3 shows the calculation results of the Sauter mean diameter (SMD) with the increasing electrical load for B100 biodiesel fuel. As seen in Figure 4 and Table 3 . the penetration length and size of the Sauter mean diameter (SMD) decrease and the spraying angle increases with increasing fuel injection pressure.

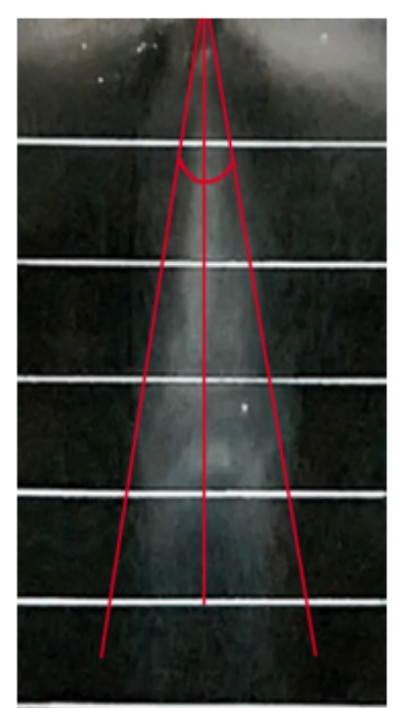

Spray Penetration: $25 \mathrm{~cm}$ Spray Angle $\rightleftharpoons 25^{\circ}$
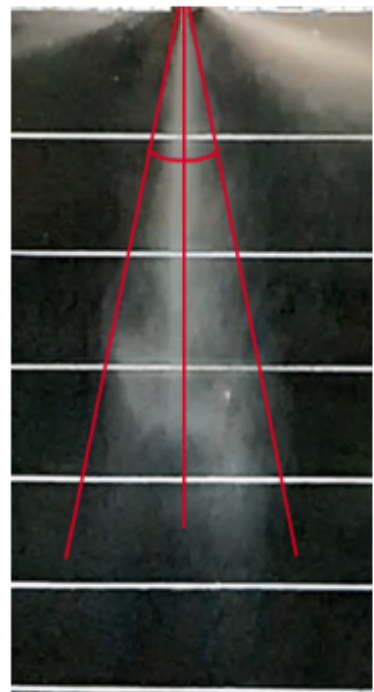

Spray Penetration: $22.5 \mathrm{~cm}$ Spray Angle $\cong 27^{\circ}$

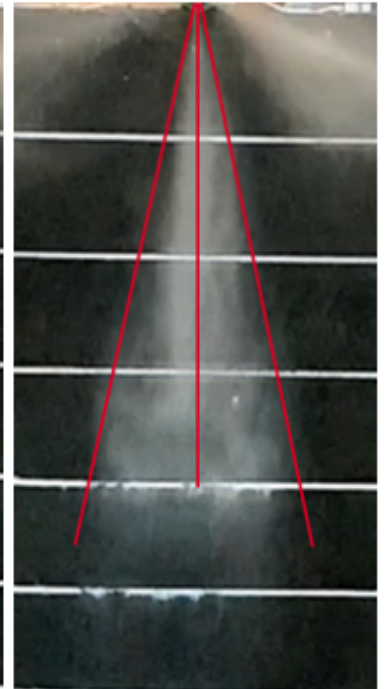

Spray Penetration: $20 \mathrm{~cm}$ Spray Angle $\doteq 29^{\circ}$

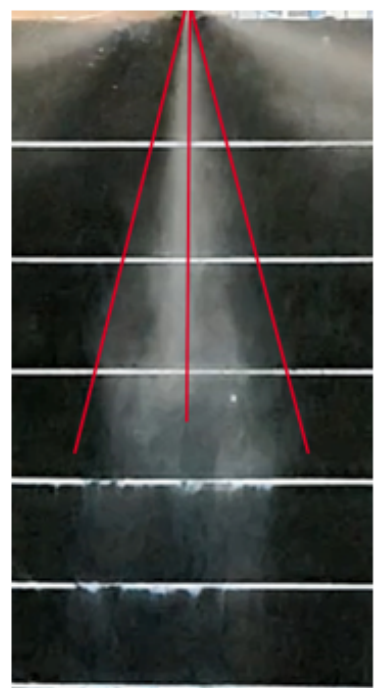

Spray Penetration: $17.5 \mathrm{~cm}$ Spray Angle $\doteq 32^{\circ}$

Figure 4. Atomization result of biodiesel fuel; (a) $200 \mathrm{~kg} / \mathrm{cm}^{2}$; (b) $210 \mathrm{~kg} / \mathrm{cm}^{2}$; (c) $220 \mathrm{~kg} / \mathrm{cm}^{2}$; (d) $230 \mathrm{~kg} / \mathrm{cm}^{2}$ 
Table 3. Sauter Mean Diameter Calculation Results

\begin{tabular}{|c|c|c|c|c|c|}
\hline No & Load & \multicolumn{4}{|c|}{ Injection Pressure } \\
\hline & & $200 \mathrm{~kg} / \mathrm{cm}^{2}$ & $210 \mathrm{~kg} / \mathrm{cm}^{2}$ & $220 \mathrm{~kg} / \mathrm{cm}^{2}$ & $230 \mathrm{~kg} / \mathrm{cm}^{2}$ \\
\hline 1 & 1000 & 0,0135 & 0,0131 & 0,0128 & 0,0123 \\
\hline 2 & 2000 & 0,0140 & 0,0134 & 0,0131 & 0,0127 \\
\hline 3 & 3000 & 0,0144 & 0,0139 & 0,0134 & 0,0129 \\
\hline 4 & 4000 & 0,0148 & 0,0144 & 0,0139 & 0,0134 \\
\hline 5 & 5000 & 0,0153 & 0,0149 & 0,0144 & 0,0138 \\
\hline 6 & 6000 & 0,0158 & 0,0154 & 0,0149 & 0,0142 \\
\hline 7 & 7000 & 0,0163 & 0,0158 & 0,0151 & 0,0146 \\
\hline \multicolumn{2}{|c|}{ Mean } & 0,0149 & 0,0144 & 0,01398 & 0,01346 \\
\hline
\end{tabular}

After testing the fuel spray characteristics with variations in the increase in injection pressure using biodiesel fuel, better atomization results were obtained at an injection pressure of $230 \mathrm{~kg} / \mathrm{cm}^{2}$. Due to the injection pressure of $230 \mathrm{~kg} / \mathrm{cm}^{2}$, it produces a spray angle of $32^{\circ}$ higher than other pressures which cause the sprayed fuel to spread more in all directions and accelerate the droplets of fuel into smaller granules. The shorter penetration length of $17.5 \mathrm{~cm}$ causes smaller flow momentum [1] and the average SMD value is 0.01346 making evaporation increase [6]. Sudarmanta also reported that the increasing pressure of injection tends to increase quality ofspray atomization, where it is occurred for all blend fuels. This result of atomization process tends to decreaseduration of ignition delay, duration of premixed combustion and diffusion combustion and total heat release [7].

3.2. Result and Analysis of Performance Test and Exhaust Emission, Biodiesel Fuel with Injection Pressure Variations.

This test was carried out to determine the performance and exhaust emissions with injection pressure variations of 200, 210, 220, $230 \mathrm{~kg} / \mathrm{cm}^{2}$ using B100 biodiesel fuel. The final results of this study are performance and exhaust emissions including brake thermal efficiency, brake specific fuel consumption, air-fuel ratio, and smoke opacity.

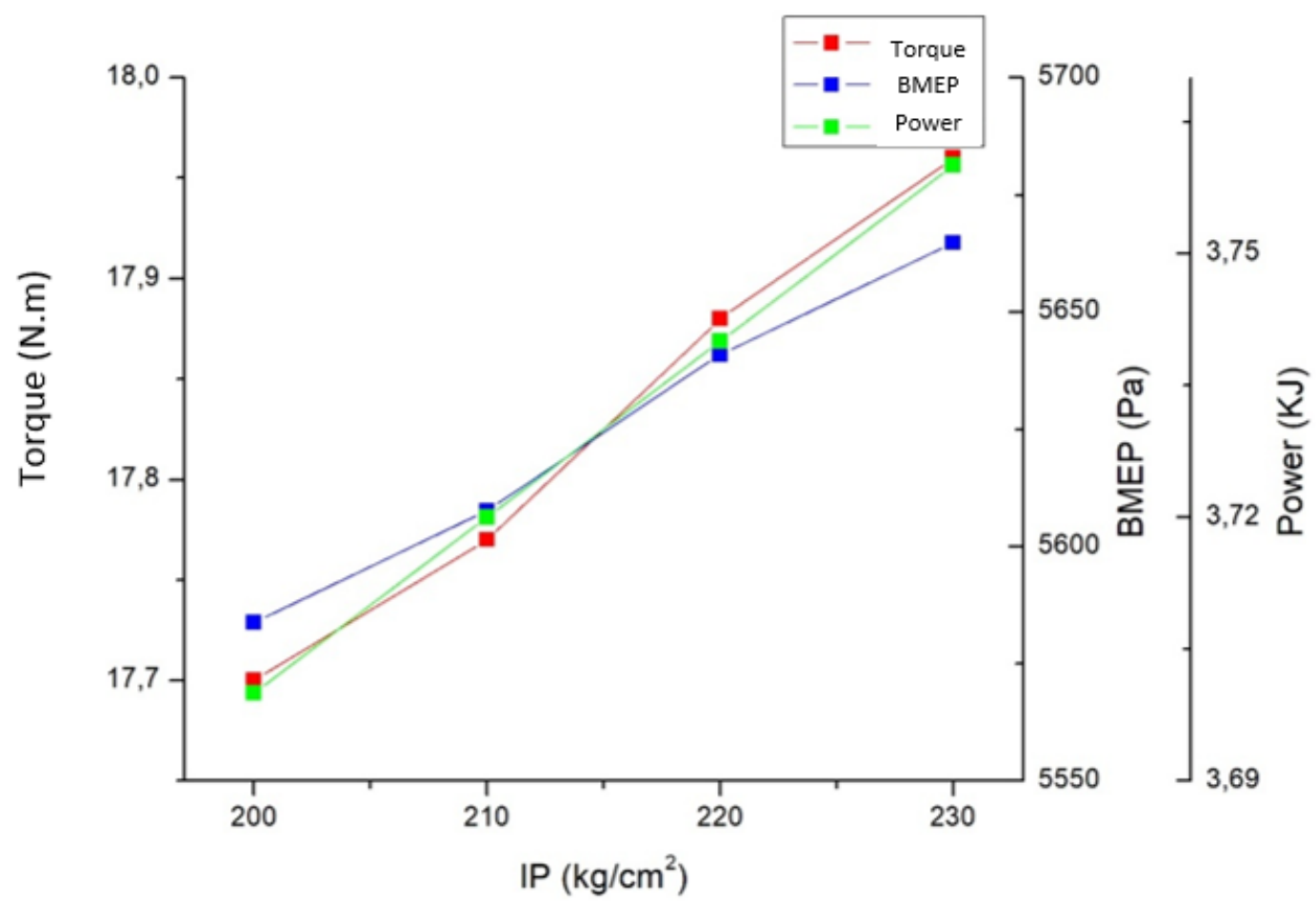

Figure 5. Power, Torque and BMEP with variation injection pressure at average of loads 


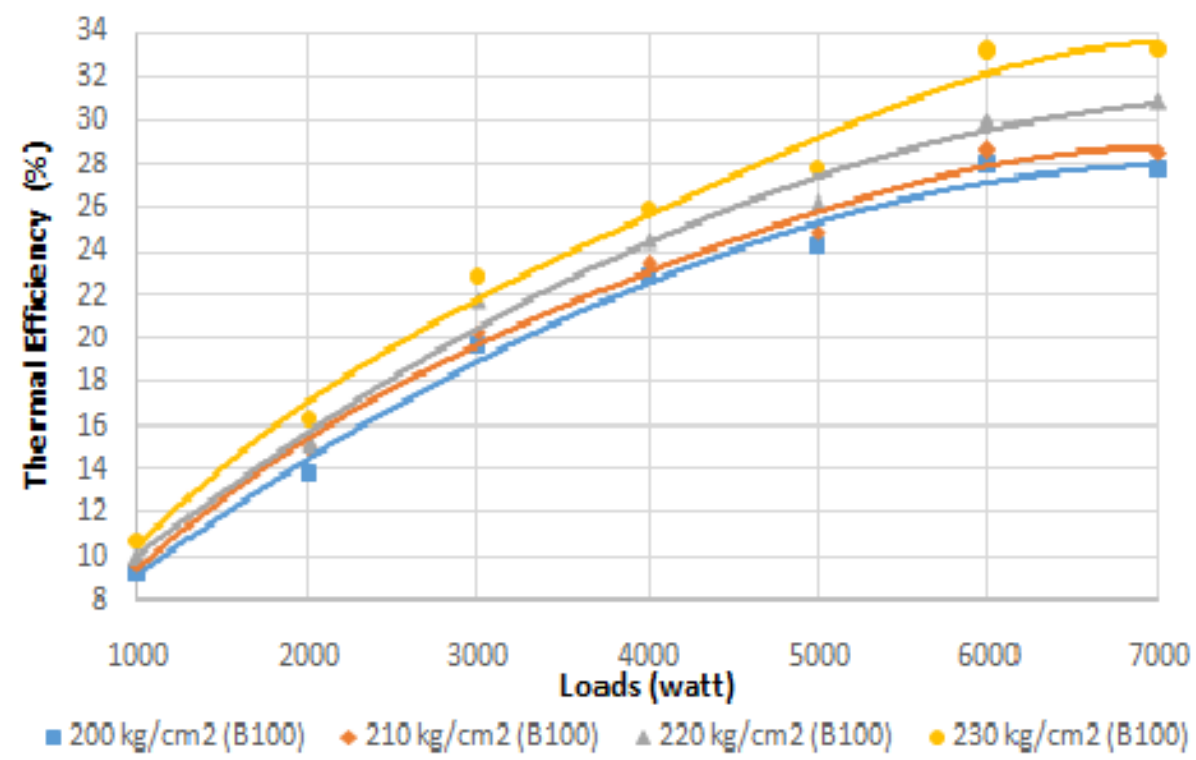

Figure 6. Thermal efficiency on variation of injection pressure versus engine loads

Figure 5 for performance parameters such as power, torque, and BMEP are relatively the same, this is because the load given to the engine rpm are similar. Figure 6 shows a graph of thermal efficiency with the increasing of loads with variations in injection pressure using biodiesel fuel. In Figure 6, it can be seen that the increasing fuel injection pressure results in higher thermal efficiency of $16.77 \%$ at a pressure of $230 \mathrm{~kg} / \mathrm{cm}^{2}$ compared to the standard pressure of $200 \mathrm{~kg} / \mathrm{cm}^{2}$. This is because the power generated by the engine increases with increasing load. Increased injection pressure results in better atomization as produced in testing spray characteristics. This results in more complete combustion. Agarwal et al reported that BTE increases with increasing fuel injection pressure at full load because higher injection pressures make it more effective in improving fuel spray characteristics and the resulting performance is better [8].

Figure 7 shows a graph of brake specific fuel consumption for the increasing of loads with variations in injection pressure using biodiesel fuel. In Figure 7, it can be seen that the increasing fuel injection pressure results in lower brake specific fuel consumption of $14.01 \%$ at a pressure of $230 \mathrm{~kg} / \mathrm{cm}^{2}$ compared to the standard pressure of $200 \mathrm{~kg} / \mathrm{cm}^{2}$. This is because the power produced by the engine increases along with the increasing of the load and also the amount of biodiesel injected into the combustion chamber will also be more. In accordance with the results of the spray characteristics test, fuel atomization is better with increased injection pressure which results in more complete combustion and causes less fuel needed. Channapattana et al reported that BSFC reduces with the increase in IP for all the fuels tested. This is due to better atomization at higher IP which exposes larger surface area of fuel droplet to the high temperature air leading to complete combustion of fuel [9].
Figure 8 shows the air-fuel ratio graph for the addition of loads with variations in fuel injection pressure using biodiesel fuel. In Figure 8 , it can be seen that the increased fuel injection pressure produces AFR which is higher by $13.31 \%$ at the injection pressure of $230 \mathrm{~kg} / \mathrm{cm}^{2}$ compared to the standard pressure of $200 \mathrm{~kg} / \mathrm{cm}^{2}$. This is because the use of biodiesel fuels with properties such as higher viscosity, density, and surface tension causes more fuel needed on the engine but produces incomplete combustion. With increasing fuel injection pressure, it produces better fuel atomization according to the more perfect spray characteristics and combustion test results.

Figure 9 shows a graph of Smoke Opacity for the addition of the load obtained from the exhaust gas generated from combustion of fuel and air with variations in fuel injection pressure. In Figure 9, from all variations in injection pressure, it serves to increase with increasing load. This is because the high temperature of the engine temperature increases. With the increasing amount of fuel entering the combustion chamber, the mixture of fuel and fuel becomes rich. Then it can be seen that the increase in fuel injection pressure results in a lower smoke opacity of $46.39 \%$ at the fuel injection pressure of $230 \mathrm{~kg} / \mathrm{cm}^{2}$ compared to the standard pressure of $200 \mathrm{~kg} / \mathrm{cm}^{2}$. This is because of better fuel atomization according to the spray characteristics test results in more complete combustion. Song J.T. This is because biodiesel is free of sulphur and aromatic. Smoke is produced from the dehydrogenization of polycyclic from aromatic processes. In addition, the unsaturated fatty acids in biodiesel also affect the combustion process. Because unsaturated fatty acids have a saturated vapour temperature that is smaller than diesel fuel. So biodiesel is more volatile and combustion can be more perfect [10]. 


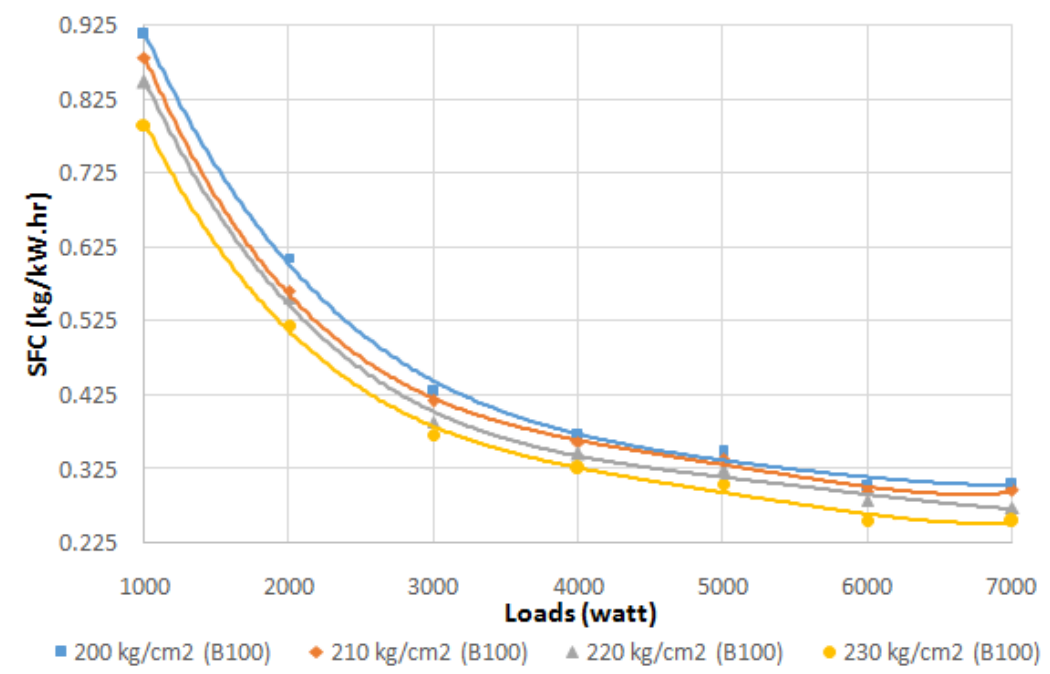

Figure 7. Specific fuel consumption versus engine loadon variation of injection pressure

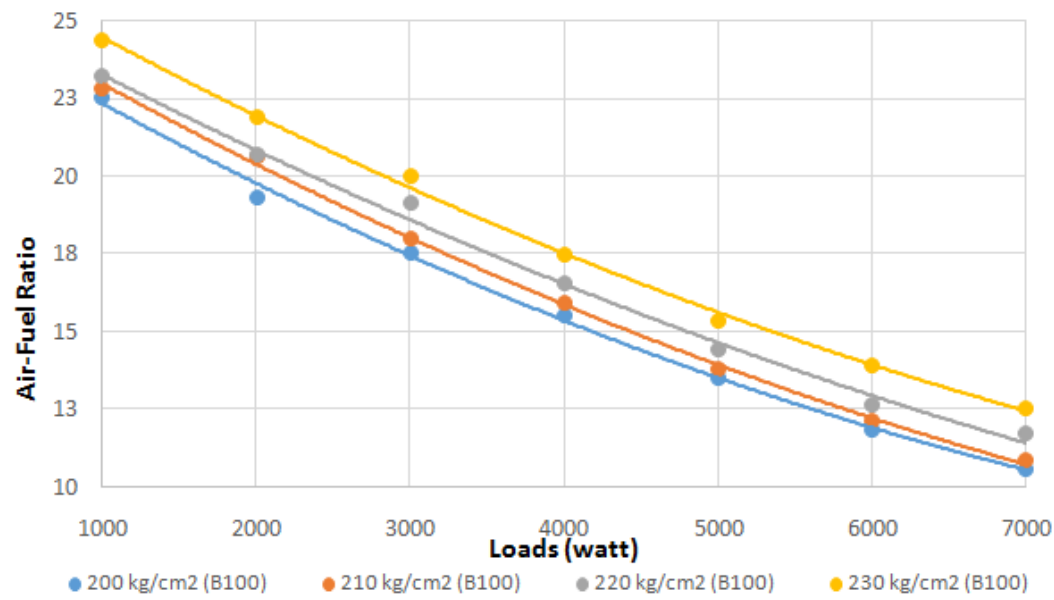

Figure 8. Air-fuel ratio versus engine loadson variations of injection pressure

\section{Conclusions}

From the experimental study on effect of injection pressure on performance and emission dieselengine DI 20 Cusing biodieselfuel, it can be drawn several conclusions.

1. Increased injection pressure results in better spray characteristics which include penetration length, spray angle, and SMD. The length of penetration and SMD decreased by $30 \%, 9.78 \%$ and the spray angle increased by $28 \%$ at injection pressure 230 $\mathrm{kg} / \mathrm{cm}^{2}$ compared to the standard injection pressure of $200 \mathrm{~kg} / \mathrm{cm}^{2}$.

2. Increased injection pressure results in better performance which includes BTE, BSFC, and AFR. BTE and AFR increased by $16.77 \%, 13.31 \%$ and BSFC decreased by $14.01 \%$ at injection pressure of 230 $\mathrm{kg} / \mathrm{cm}^{2}$ compared to the standard injection pressure of $200 \mathrm{~kg} / \mathrm{cm} 2$.

3. Increased injection pressure results in better exhaust emission which include Smoke opacity. Smoke opacity decreased by $46.39 \%$ at injection pressure of 230 $\mathrm{kg} / \mathrm{cm}^{2}$ compared to the standard injection pressure of $200 \mathrm{~kg} / \mathrm{cm}^{2}$.

\section{References}

[1] B. Sudarmanta and D. Sungkono, "Transesterifikasi crude palm oil dan uji karakteristik semprotan menggunakan injektor motor diesel," Jurnal Teknik Mesin FTI-ITS, vol. 5, no. 2, 2005.

[2] A. S. Ahmad and B. Sudarmanta, "Studi eksperimen unjuk kerja mesin diesel sistem dual fuel dengan variasi tekanan penginjeksian pada injektor mesin yanmar tf55 r di," 2017. 


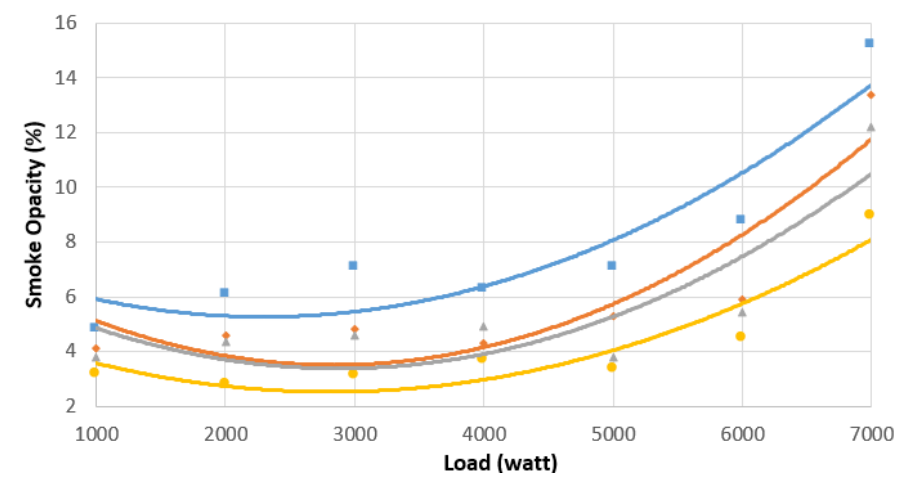

Figure 9. Smoke opacity versus engine loads on variation of injection pressure

[3] K. Mutyalu, V. Das, and K. S. Rao, "Effect of fuel injection pressure on performance and emission characteristics of di-ci engine with shea olein biodiesel," Materials Today: Proceedings, vol. 5, no. 1, pp. 494 500, 2018.

[4] D. Kawano, Internal Combustion Engine, Diesel. Surabaya: ITS Press, 1999.

[5] A. H. Lefebvre and V. G. McDonell, Atomization and Sprays. CRC Press, 2017.

[6] M. T. Shervani-Tabar, M. Sheykhvazayefi, and M. Ghorbani, "Numerical study on the effect of the injection pressure on spray penetration length," Applied Mathematical Modelling, vol. 37, no. 14-15, pp. 7778-7788, 2013.

[7] R. M. W. S. . S. D. Sudarmanta, B., "The atomization and combustion characteristics of biodiesel and fossil diesel fuel bland," Jurnal Industri , 1-12., 2006.
[8] A. K. Agarwal, A. Dhar, J. G. Gupta, W. I. Kim, K. Choi, C. S. Lee, and S. Park, "Effect of fuel injection pressure and injection timing of karanja biodiesel blends on fuel spray, engine prformance, emissions and combustion characteristics," Energy Conversion and Management, vol. 91, pp. 302-314, 2015.

[9] S. Channapattana, A. A. Pawar, and P. G. Kamble, "Effect of injection pressure on the performance and emission characteristics of vcr engine using honne biodiesel as a fuel," Materials Today: Proceedings, vol. 2, no. 4-5, pp. 1316-1325, 2015.

[10] J.-T. Song and C.-H. Zhang, "An experimental study on the performance and exhaust emissions of a diesel engine fuelled with soybean oil methyl ester," IMhechE, vol. 222, no. D, 2008. 